\title{
The Microcredit-Business Performance Relationship: Program Delivery Services as Mediator
}

\author{
Rosman Mahmood ${ }^{1 *}$ \\ Ahmad Suffian Mohd Zahari ${ }^{1}$ \\ Sakinah Mat Zin² \\ 1 Universiti Teknologi MARA (Terengganu) \\ 2Universiti Teknologi MARA (Kelantan) \\ ‘E-mail: rosmanma@tganu.uitm.edu.my
}

Doi:10.5901/mjss.2015.v6n6s2p691

\begin{abstract}
The objective of this study is to investigate the relationship between the microcredit program and the performance of microenterprises, as well as assessing the impact of the intermediary service delivery system on the relationship between the microcredit program and the performance of microenterprises. Primary data were collected from 756 micro-enterprises under the microcredit program Amanah Ikhtiar Malaysia (AIM) and Tabung Ekonomi Kumpulan Usaha Niaga (TEKU N), which are two most active microcredit programs in Malaysia. The multiple regression analysis showed a significant positive correlation between the performance of microcredit program and microenterprises. Empirical findings also explain the elements of modes of financing under the management of credit products, as well as the two elements under the social development programs (entrepreneurship development, monitoring and supervision) as having a clear effect of the mediators of the relationship between the microcredit program and the performance of microenterprises. However, the study found that elements of operational efficiency in the management of credit products do not affect the relationship between the two variables. These findings lucidly reveal the importance of balance between the efficiency of the management of credit products and a program of social development in the service delivery system of microcredit program.
\end{abstract}

Keywords: microcredit; performance; operational; microenterprises; service

\section{Introduction}

Currently, microcredit programs have become a critical mechanism in the growth and development of small and micro enterprises in most countries. Although the concept of microcredit has long existed, the "Experimental Grameen Bank" project which led to the establishment of the Grameen Bank in Bangladesh is recognized as a substance for the development of microcredit programs globally, particularly in developing countries (Woodworth, 2000). The rapid development of the microcredit program is not only conspicuous from the point of the institutions involved, but also the number of customers and the participation of the poorest in the programs offered. The number of institutions providing microcredit showed a significant upsurge in the past decade. From 618 institutions in 1997, the figure had increased to 3,552 units in 2007 and 3,589 units for two years later. The number of customers affected in 2007 was about 13.5 million people, and continued to increase dramatically to 190.1 million subscribers in 2009. Until the end of 2011, there were a total of 3,703 institutions offering microcredit program and the total numbers of borrowers has grown spectacularly to over 195 million, of whom 124.3 million are among the poorest. This positive development shows that microcredit programs have the ability to act as a catalyst to the development of entrepreneurial activities at the grassroots level (Bhatt et al., 1999) and generate economic growth in many countries (Colman, 2006). Involvement of target groups in entrepreneurial activities through microcredit program is to increase revenue, improve living standards and eventually reduce poverty (Makina \& Malobola, 2004).

The main objective for the establishment of the Grameen Bank is to improve the living standards of the poor through the provision of credit assistance, besides challenging the conventional loan (Berko \& Gueullette, 2003). Credit delivery techniques which implemented by the Grameen Bank do not require collateral as required in other conventional financial institutions (Zeller et al., 1997). Capital injection through microcredit programs brings the poor and marginalized individuals out of the poverty cycle (Woller \& Woodworth, 2001). In addition to the provision of credit, microcredit program 
also typically offers various support programs including entrepreneurship and business training, technical assistance, social development programs, expansion of knowledge and leadership skills (McKernan, 2002).

Amanah Ikhtiar Malaysia (AIM) is one of the microcredit programs on the Grameen Bank model introduced in Malaysia in 1987. The microcredit program in question is a replica of the Grameen Bank, the oldest and largest in Asia (Conroy, 2002). In 1995, the government has set up a microcredit program namely Tabung Ekonomi Kumpulan Usaha Niaga (TEKUN), which specifically to sustain the needs for capital among small traders and hawkers. Based on the success of both programs, the small capital financing through microcredit program continues to be an important approach to the government to increase entrepreneurial activities among the target groups. To guarantee continued development and improvement of the program, the government has prepared an action plan to provide opportunities for greater involvement of Development Finance Institutions (DFIs) and credit cooperatives in delivering financial products. The initiative is complemented by the existing microfinance programs which are sponsored by the government such as AIM and TEKUN (Bank Negara Malaysia, 2007). Among the DFls involved are Bank Simpanan Nasional (BSN) (offering microcredit to entrepreneurs who run activities for the non-agricultural business), AgroBank (for entrepreneurs who are engaged in agricultural activities) and Bank Rakyat (specifically for cooperative members engaged in smaller enterprises). To warrant that microcredit programs continue to serve as a mechanism to meet the financial needs of small businesses, in 2003, the Council of Small and Medium Enterprises Development has approved the establishment of the framework of a comprehensive microfinance institution to serve as a catalytic agent for the sustainable development of small enterprises in Malaysia. The framework encompasses the development of product specifications, policies and procedures for the management of micro-finance, organizational structure and the supervisory framework for regulating microfinance activity. The outline developed is used as a guide and reference for the development of financial institutions and other financial institutions that wish to provide micro financing (Che Zakiah, 2004). The laid framework clearly shows the importance of microcredit program management in a more systematic way in ensuring the effectiveness of the program which will affect the performance of small enterprises involved.

Most studies conducted on the microcredit program mainly focus on the socioeconomic impacts of the program on the target group in terms of income, savings, employment opportunities, improved living standards and asset ownership. In addition, there are also discussions among microcredit practitioners and scholars who look from the perspective of selfreliance (performance) microcredit program and issue of repayment. There are less researches precisely focused on the importance of service delivery in the microcredit program and performance of micro enterprises. Although there are studies that draw conclusions about the importance of service delivery (Pellegrini, 2015), the explanation of the theoretical development of the discipline is still limited (Ponsignon et al., 2011; Kwortnik \& Thompson, 2009; Tax \& Stuart, 1997, Goldstein et al., 2002; Hill et al., 2002). Accordingly, the literature associated with service delivery in the relationship between microcredit program and firm performance is scarce. Based on these requirements, this research attempts to make empirical analysis on the influence of the microcredit program performance and the importance of service delivery on the relationship between microcredit program with micro and small enterprises (MSEs) performance.

\section{Literature Review and Hypothesis Construction}

In general, microcredit refers to small loans to help the poor or low-income groups. Bhatt et al. (1999) relate microcredit loans to small size businesses as low as USD50 to help the poor improve their lives through economic activity. Microcredit program is defined as a business providing small loans to the poor in order to generate higher revenue through the economic activity undertaken (Woller \& Woodworth, 2001). More precisely, the microcredit program is considered as an initiative providing a wide range of financial services including lending, payment services, savings, money transfer and the provision of insurance to the poor and low-income households to help them carry out micro enterprises (Asian Development Bank, 2000). In addition, the management of credit of the microcredit programs also contains social development programs, such as training and mentoring, monitoring, savings and motivation. The main goal of the Grameen Bank microcredit program is to alleviate poverty and improving the living standards of the target groups by promoting their participation in economic activities. The issues to be debated and researched among scholars and practitioners of microcredit programs are related to the ability of the independent microcredit program itself. The microcredit program has the capacity to generate their own income in order to issue loans to the target group without constantly depending on the source of funds from abroad and more so the government. In fact, the capability of each independent microcredit program has a close relationship with the performance of the program and the economic activities carried out by the customers. In short, the success of microcredit programs and the performance of the economic activity are depend on the delivery mechanism practiced. The efficiency and success of microcredit programs will also have a positive impact on customers (Painter \& Tang, 2001; Seibel \& Parhusip, 1998). 


\subsection{Microcredit and firm performance}

The lack of financial capital is the main constraint faced by small enterprises, particularly in the less developed countries (Reddy, 2007) and regarded as a critical issue among researchers in these disciplines. Based on the success of the Grameen Bank in Bangladesh, policy makers see the microcredit program as a highly effective approach to solve the constraints inherent in the development of the MSEs of the given countries. The rapid expansion of the program showed that microcredit programs have become an important mechanism used by many countries, including developed countries (Armendáriz \& Morduch, 2010). Even though the main objective of microcredit program is for poverty alleviation, the ability to generate economic growth of the target groups through entrepreneurial activity is giving a big impact on the relationship between the microcredit program performance and small enterprises' development. The credit facility will encourage those aspiring to enter into business or enhance business activities, so as to earn higher incomes, improve living standards and reduce poverty among them (Hietalahti \& Linden, 2006).

Studies on the impact of microcredit program empirically show a positive effect on MSEs' performance (Rosman \& Mohd Rosli, 2013; Norma \& Jarita, 2010). This is proven from the increase in the rate of profit earned (Alam, 2013; Fatimah Salwa et al., 2013; Hietalahti \& Linden, 2006) and a rise in employment opportunities (Arinaitwe, 2006; Khandker et al., 1998). Enterprise performance improvement greatly influences the targeted income and expenditure (Norma, 2011; Hietalahti \& Linden, 2006; Sukor, 2000), raising savings (Copestake et al., 2001), asset possession (Bhatt et al., 1999; Khandker, 1999), creating the family and society's wealth and reassurance (Ang, 2004). The stimulus of microcredit programs on MSE's performance is a very important issue, and it needs to be carefully analyzed as to safeguard the survival of the microcredit program itself and the MSEs' performance. Based on the importance of microcredit programs, the following hypothesis is presented.

H1: Microcredit is positively associated with firm performance

\subsection{Microcredit, service delivery system and firm performance}

The delivery mechanism is one important factor that may determine the competitiveness of a business. Service delivery is the method of services provided to customers (Tax \& Stuart, 1997). Delivery system facilitates the firm in the strategy implementation by providing management resources such as assets, capabilities, firm attributes, information and knowledge (Draft, 1983; Porter, 1981). Barney (1991) classifies the resources into three types: physical, human and organizational resources. Aligning the target market, the concept of service and service delivery is crucial for designing business strategies and achieve performance levels, customer satisfaction, retention and overall profitability (Ponsignon et al., 2011). In the context of the microcredit program, the implementation of an efficient delivery mechanism is very important to enhance the management effectiveness and program supervision. The efficiency of microcredit program implementation and management of resources will guarantee the survival of the program and improve MSEs' performance (Painter \& Tang, 2001; Seibel \& Parhusip, 1998). The vulnerability of management practices, particularly in the accounting information system to service the loan, monitoring and follow-up will affect the performance of the microcredit program (Dokulilova et al., 2009; Bhatt et al., 1999). Theory of Resource Based View (RBV) highlights on the importance of internal resources (including human resources) in determining competitive advantage and firm performance. However, not all resources have such capabilities. According to Hart (1995), a unique resource that will be a strategic asset to the firm will confer a continuous competitive advantage for the firm. Correspondingly, the management should give priority to the selection and management of resources to encourage the most efficient firms to compete effectively (Rumelt, 1984). In the context of the microcredit program management, Getubig et al. (1997) outline nine factors that inspire the success of a microcredit program, namely vision, viable strategic planning, affordable interest rates, savings mobilization, credit products, operational efficiency, risk management, human resource development and customer support services.

Although financial aid is the main thrust for the implementation of microcredit programs, most institutions are implementing programs that replicate the Grameen Bank. Microcredit in particular provides various support programs that complement the credit products to improve the socioeconomic status of the target group. It emphasizes human capital development such as skills upgrading training, awareness and the credit product. Credit facilities available to the poor are meant to facilitate the target group to purchase capital inputs, thus promoting productive self-employment activities. To reach a larger target group and provide a more comprehensive benefit, microcredit programs have a distinct and different approach from the method used by conventional financial institutions. Generally, the implementation of Grameen Bank microcredit programs involves two important mechanisms of credit products and social development programs. 


\subsection{Product credit}

Provision of finance is the central drive of the microcredit program. Among the important issues in credit product is related to the manner of financing. According to a report, the "Bank Poor 96" credit product model has unique characteristics to attract customers, including the nature of products, easily obtainable, timely provision of credit, maturity and reasonable "grace period", smaller repayment installments and; organized and affordable loan size (Getubig et al., 1997). Positive relationship between credit products and performance is explained by Seibel and Parhusip (1998), and Christen (1997). There are several scholars that touched on the system adopted including the repayment of loans (Sarap, 2014; Singh, 2012; Deininger and Liu, 2009), the number of loans disbursed (Fatimah Salwa et al., 2013; Obamuyi, 2009; Eze \& Ibekwe, 2007) as well as the loan repayment period (Roslan \& Karim, 2009; Derban et al., 2005). A study conducted by Seibel and Parhusip (1998) on the microcredit program, Advancement Centre for Agriculture Committee (CARD) in the Philippines found that the performance achievable depends on the strength of credit discipline that covers the repayment method, timelines to refund, rise in the number of repeat loans and alternative arrangements to manage loan repayments. Most of the loans issued are in accordance with the approach practiced by Grameen Bank through group lending (Estapé-Dubreuil \& Torreguitart-Mirada, 2010).

The management practices of credit products through group lending (Rubach et al., 2010), as well as the schedule of repayment and flexible collateral (Armendáriz \& Morduch, 2005) are perceived as the factors that determine the success of microcredit programs in developed countries (McKernan, 2002). Microcredit programs in the United States have different financing methods than that of developing countries. They do not lend by group, so they failed to utilize the benefits of the network (Richardson, 2009) thus affecting the performance of the program and MSE's involved. On that account, microcredit programs in developed countries were less successful than those of developing countries (Hung, 1999). For most programs such as the Grameen Bank microcredit replica, AlM participants are required to attend weekly meetings. Such an approach turns out to be a very effective mechanism to guarantee the repayments by customers. Group members will be responsible if there are members of the group who fail to pay back their loans (Zapalska et al., 2007; Guttman, 2007). In addition to the loan repayment method, the success of microcredit programs also depends on the amount of loans issued (Pereira \& Mourao, 2012; Norma \& Jarita, 2010; Roslan \& Karim, 2009; Hulme \& Mosley, 1996). In accordance with the Grameen Bank approach, the amount of credit granted will be increased by the loan. Studies conducted by the Fatimah Salwa et al. (2013) and Sukor (2000) demonstrate a growing number of loans granted have resulted in creating more successful microcredit programs and the enterprises involved. Based on the importance of the factors in the management methods of financing credit products on MSEs' performance, this study focuses on the following hypothesis.

$\mathrm{H} 2$ : The effect of microcredit on firm performance is mediated by the modes of financing

In addition to product characteristics and a unique credit, microcredit program performance and participating small enterprises also depends on the efficiency of operations in the issuance of a loan. Operational efficiency is defined as the ability to utilize optimum resources in activities linked to the process of producing credit financing to customers. The loan procedure can be viewed in terms of the time span for loan approval, service charges or interest rates and loan conditions imposed on borrowers. The efficiency in the production process of the loan will not only attest the success of microcredit programs, but also influence the performance of small enterprises involved (Painter \& Tang, 2001). Based on a review of the five Monetary Financial Institutions (MFIs) in Indonesia, Raviez (1998) discusses the need for a more convenient loan procedure and systematic management supervision of the credit system that can affect the success of microcredit programs. The importance of operational efficiency, particularly in the management of internal resources is also emphasized by Gibbons and Meehan (1999) in determining the performance of the microcredit program. The acceptable interest rate is also vital for the survival of the program and the performance of MSEs (Christen, 1997; Gibbons \& Meehan, 1999). Bhatt et al. (1999) look at some of the failure factors of microcredit programs in the United States, which are caused by laws manipulating over the interest rates charged to clients. according to Hulme and Mosley (1996), the imposition of higher interest rates could accelerate the ability of independent microcredit institutions, but it will limit the range of customers. However, Gibbons and Meehan (1999) argue that there are no conflicting performance issues between microcredit programs with outreach. Despite the high interest rates charged the greater number of loans and the more efficient the management will be the performance of institutions and MSE's involved tend to improve (Gibbons \& Meehan, 1999; Christen, 1997). A study conducted by Dokulilova et al. (2009), Farrington (2000), McDonald (2000) and Brand (2000) also explore from the perspective of the importance of efficiency in the management of the microcredit program. The findings may help elucidate a more efficient operation management in higher loan production capabilities to achieve better performance. This finding leads to the following hypothesis.

H3: The effect of microcredit on firm performance is mediated by operational efficiency 


\subsection{Social development programs}

In addition to providing financial assistance, most microcredit programs also offer support services to improve the performance of the target groups. There are two main elements of focus in social development programs of entrepreneurship-monitoring and supervision. Target groups are not only facing capital constraints to operate a business, but also lack effective skills and knowledge in business management (Rosman \& Mohd Rosli, 2013; Sharma \& Zeller, 1997). To overcome the shortcomings of the microcredit program, practitioners feel that customers should be exposed to the values and practices of entrepreneurship fundamentals in the business and also be motivated instead of solely participating in the provision of credit. The Grameen Bank microcredit programs such as AIM (Malaysia), K-REP (Kenya), Zambuko and PULSE (Zimbabwe), GAF Stokvel (South Africa) are examples of microcredit programs that give special emphasis on training and mentoring. Training is important for applying entrepreneurial competence among customers. In fact, according to Light and Pham (1998), there is also a microcredit program that requires prospective borrowers to sit and pass the training program held before the loan is issued to them.

Involvement of operators in training and personal development programs will improve business management skills and provide a large space for increasing social capital in the business environment. They have the opportunity to reach out to various stakeholders including government agencies that provide assistance and support, competitors, customers and suppliers. Skills and experience gained will reduce business failure and moreover, increase productivity among the participating entrepreneurs (Ubeda-García, 2005; Bruwer \& Haydam, 1996), intensify viability (Webster et al., 2005), and consequently confer a positive influence on the performance of entrepreneurial activity (Simpson et al., 2004). Studies conducted (Ubeda-García, 2005; Chinomona, 2013; Norma \& Jarita, 2010; Aragón-Sánchez et al., 2003; Fraser et al. 2002; Zinger et al., 2001; Copestake et al., 2001) empirically prove that the training and guidance contributes to an important effect on enterprise performance In addition to training and coaching, performance and customer microcredit programs also rely on the mandatory savings program. Savings is regarded as a source of capital for production of loans to customers (Gibbons \& Meehan, 1999), determinants of the microcredit program survival, performance of the MSEs, impact on the economy of the poor which including the preparation of economic shocks and future ability to self-finance investment (Berg, 2010), and proliferation in the confidence of the poor (Singh, 2012). Therefore, entrepreneurship development programs are treated as an important complementary factor to grant microcredit program which will promote the performance of MSEs. Based on the literature review, we present the following hypothesis.

$\mathrm{H} 4$ : The effect of microcredit on firm performance is mediated by entrepreneurship development

In addition to the management of financial and entrepreneurship development programs, MSE's performance is also dependent on the support provided by the MSEs' microcredit program for entrepreneurs involved. The microcredit program helps customers to use their entrepreneurial skills acquired while monitoring their overall socioeconomic aspects which based on the "sixteen decision" (Gibbons, 1994; Khandker et al., 1995). The customer support service programs involve all types of support as well as credit products aimed at enhancing the skills of the customers and improve their business performance. Monitoring should be done to prevent abuse of the loan capital provided. Without credit monitoring, the facility may be used for other purposes and not for business activities.

The issue of weaknesses in management, particularly financial, marketing and operations is a critical problem among small businesses. Microcredit program staff should make regular visits and ongoing mentoring for the purpose of monitoring the use of credit financing (Anku-Tsede, 2014; Obamuyi, 2009). Coaching and mentoring are important to ensure operator conduct business in accordance with the business practices and strategies. Exposure to systematic methods of financial management, implementation of an effective marketing strategy and adhering to the needed values of entrepreneurship to become successful in their business are among the aspects required by MSEs' operators. According to Norma and Jarita (2010), mentoring and exposure to business fundamentals are usually given at each weekly meeting. Accordingly, the customer should always be monitored and supervised to warrant their business performance (Mohammmed Ashraful \& Harbin, 2009). Positive relationship between the monitoring and supervision of the participating small enterprises' organization's performance is explained by Seibel and Parhusip (1998). Based on the importance of customer support for the performance of the MSEs, the following hypothesis is given.

H5: The effect of microcredit on firm performance is mediated by monitoring and supervision

\section{Research Methodology}

\subsection{Data source}

AIM and TEKUN are two of the government agencies offering microcredit programs in Malaysia. They are considered as 
top agencies with many participants and disbursement. Other agencies involved in the programs are Non-Government Organizations (NGOs), religious institutions and commercial banks. Being innovative microcredit programs in encouraging economic growth in poor communities, most of AIM and TEKUN recipients are MSEs in Kelantan. Hence, data collection for this study is being focused to MSEs in Kelantan.

The population for this research is 30,446 (AIM) and 16,432 (TEKUN) borrowers obtained from the AIM's state office and TEKUN's headquarters. The population was segregated into strata (districts). A representative sample was drawn from the population to participate in this research. 380 samples (AIM) and 376 samples (TEKUN) were chosen. MSEs' owner-manager was issued a self-administered questionnaire. The manager was considered as fully responsible for decision making (Alam, 2013) and good at identifying and solving problems in his or her firm (Bateman \& Snell, 1999). Compared with other data collection methods such as by mail or email, face to face interview method and distribution of questionnaires to the respondents were carried out in this study.

\subsection{Measures}

\subsubsection{Firm performance}

Firm performance is a dependent variable in this study. Based on an adapted version of Kotey and Meredith (1997), and Gadenne (1998), subjective performance measures were used. Items included are sales revenue, profits earned, production mitigation costs, business growth and contribution to the local community, the size of the market, job creation, business stability, market requirements, customer satisfaction and business networking. The performance of their business for the past three years was appraised respondents using a 7-point scale, ranging from " 1 = strongly dissatisfactory" to "7 = strongly satisfactory".

\subsubsection{Program delivery services}

The delivery system is a method used in the management and implementation of microcredit programs. There is a total of 13 items that were analyzed in the study related to the delivery system namely service charges imposed on customers, time to approve a loan, the imposed loan regulations, the amount disbursed, the method of repayment of loans, the repayment period, loan capital supervision, development programs, the commitment of the staff, monitoring and evaluating the effectiveness of the project, training programs provided, exposure to the basics of business and advisory services. Respondents are required to explain their actual satisfaction on all items based on a scale of 7 points, "1 = very dissatisfied and $7=$ very satisfied". Principal components factor analysis with varimax rotation was performed to better reveal the factors structure among the 13 items. The results of factor analysis of all 13 items were divided into four factors which are modes of financing, operational efficiency, entrepreneurship development and monitoring and supervision. Table 1 shows the reliability tests for several constructs used in the study with Cronbach's alpha higher than the 0.7 value, as suggested by Nunnally (1978). Although the Cronbach's alpha for the monitoring and supervision is only 0.65 , the value is still acceptable as described by Sekaran (1992).

Table 1. Reliability Tests

\begin{tabular}{|lcc|}
\hline Construct & Items & Cronbach's Alpha \\
\hline Modes of financing & 3 & 0.719 \\
Operational efficiency & 3 & 0.908 \\
Entrepreneurship development & 4 & 0.841 \\
Monitoring and supervision & 3 & 0.650 \\
Business performance & 13 & 0.895 \\
\hline
\end{tabular}

\subsubsection{Microcredit and control variable}

In this study, the microcredit program is measured based on the current loan amount incurred by the customer. This measurement method has been used by many researchers which including Hietalahti and Linden (2006). Two control variables are used in the analysis which are the age and experience of business entrepreneurs in business. Both variables are measured respectively based on the number of businesses operated and the period (year) of the respondent's involvement in the business. 


\section{Findings and Discussion}

Before the multiple regression analysis is done, some tests were carried out to determine the reliability of the data to enable further analysis is conducted including normality, multicollinearity, independence of residuals and outliers. Table 2 depicts the means, standard deviations and correlations. From a large number of samples, it is assumed that there are sufficient and parametric data to be analyzed. Based on the value of tolerance (greater than 0.2 ) and variance inflation factor (VIF) (less than 10), it can be concluded that there is no multicollinearity problem since both are in an acceptable range.

Table 2. Descriptive Statistics and Correlations

\begin{tabular}{|c|c|c|c|c|c|c|c|c|c|c|}
\hline Variable & Mean & SD & 1 & 2 & 3 & 4 & 5 & 6 & 7 & 8 \\
\hline 1. Age of business & 12.516 & 4.464 & 1.000 & & & & & & & \\
\hline 2. Entrepreneur's experience & 5.9696 & 2.669 & $-0.083^{\star *}$ & 1.000 & & & & & & \\
\hline 3. Microcredit & 6779.2 & 5927.6 & 0.009 & $0.067^{*}$ & 1.000 & & & & & \\
\hline 4. Modes of financing & 5.0128 & 0.830 & -0.028 & $0.237^{\star \star \star}$ & $0.101^{\star *}$ & 1.000 & & & & \\
\hline 5. Operational efficiency & 4.7302 & 1.334 & $0.073^{\star *}$ & $0.145^{\star \star \star}$ & $0.114^{* *}$ & $0.527^{\star \star \star}$ & 1.000 & & & \\
\hline 6. Entrepreneurship development & 4.5628 & 1.046 & -0.080 ** & $0.210^{* \star *}$ & -0.006 & $0.185^{\star \star \star}$ & $-0.130 * * *$ & 1.000 & & \\
\hline 7. Monitoring and supervision & 5.1226 & 0.769 & -0.035 & $0.205^{\star \star *}$ & $0.064^{*}$ & $0.567^{\star \star *}$ & $0.259 * \star \star$ & $0.312^{* \star *}$ & 1.000 & \\
\hline 8. Performance & 5.0764 & 0.690 & $-0.085^{\star *}$ & $0.574^{\star \star *}$ & $0.106^{* *}$ & $0.458^{\star \star *}$ & $0.202^{\star \star \star}$ & $0.369 * * *$ & $0.419 * \star *$ & 1.000 \\
\hline
\end{tabular}

The results are presented in Table 3. Model 1 excludes microcredit, whereas the model 2 includes the program. All the Rsquared values are high, which are rarely seen in a cross-sectional study, probably due to the large sample size and number of explanatory variables in the present study.

Table 3. Multiple Regression Analysis

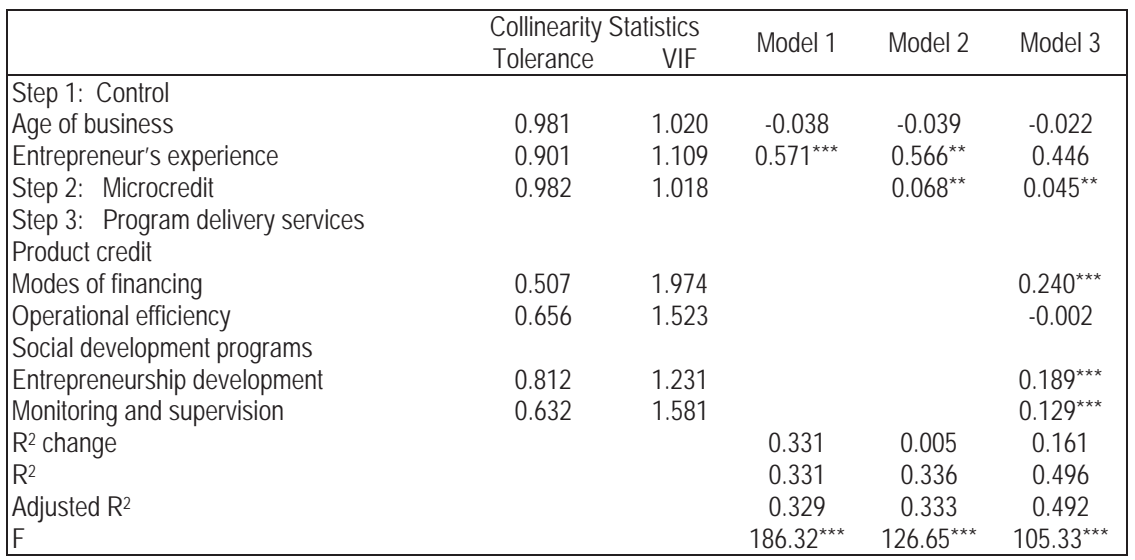

Note: Enterprises performance as dependent variable; ${ }^{*} p<0.10,{ }^{* \star} p<0.05,{ }^{\star \star \star} p<0.01$

In model 1, the control performed on two variables, namely age, business and business experience among entrepreneurs of MSEs. From the two variables, business operators' experience among the operators variable that correlates with business performance. To see the relationship between the program and the performance of MSEs' microcredit, microcredit variables and all control variables are included in the analysis. The findings on the influence of microcredit programs on MSE's performance are described in model 2. Although the $\mathrm{R}^{2}$ showed little change, it was enough to prove that microcredit had a positive and significant impact on the MSEs' performance $(\beta=0.068, p<0.05)$ and supports hypothesis 1 . This finding explains that microcredit programs have a big impact on the performance of small enterprises involved. Assistance in the form of credit and various social development programs provided under microcredit programs has an explicit major impact on the performance of MSEs'.

In order to test the main effect (for hypothesis 2 until 5) of control variables, the microcredit program and all four 
variables under which the service delivery; namely modes of financing, operational efficiency, entrepreneurship development, monitoring and supervision were tapped in the study. The findings are presented in Model 3. A significant change was observed in $\mathrm{R}^{2}(\Delta \mathrm{R} 2=0.161, p<0.01)$. Positive effect on the MSEs' performance were indicated by modes of financing $(\beta=0.240, p<0.01)$, entrepreneurship development $(\beta=0.189, p<0.01)$ and monitoring and supervision $(\beta$ $=0.129, p<0.01$ ). These findings confirmed that hypotheses 2,3 and 5 explained that the performance of the program and the reliance of small enterprises on the service delivery system of microcredit programs involved modes of financing, entrepreneurship development, monitoring and supervision. However, the association between operational efficiency and MSEs' performance is not significant $(\beta=0.002)$, where this hypothesis 4 was not confirmed.

\section{Conclusions}

This article scrutinizes the relationship between microcredit programs and service delivery program on the performance of MSEs'. Data were obtained from a total of 756 samples of two major microcredit programs in Malaysia namely AIM and TEKUN through survey methods. The multiple regression analysis showed that microcredit programs have a significant positive influence on the performance of MSEs'. This finding is consistent with studies by Rosman and Mohd Rosli (2013), Hietalahti and Linden (2006). A key issue in the development of MSEs' particularly in many developed countries is related to the lack of capital (Reddy, 2007; Arinaitwe, 2006; Tehrani \& White, 2003). Despite the small numbers of the provision of capital, a variety of non-credit programs have a positive influence on the growth of MSEs' at the grassroots level, either to start a business or expand an existing one. It is clear that the financial assistance provided, allows the target groups to be more productive in generating their income through entrepreneurial activities. Henceforth, microcredit program has become an important mechanism among policy makers in the development of the MSEs'.

In addition to the extension of credit, microcredit programs also provide various social development programs to complement the issued loan capital (McKernan, 2002). However, the implementation of the two programs does not guarantee better performance of the MSEs, because it depends on the method of microcredit program delivery services. The study had 13 elements in the delivery service system connected to the microcredit program of Grameen Bank. Based on the factor analysis, the studies have classified four factors; namely modes of financing, operational efficiency, entrepreneurship development, monitoring and supervision. Statistical tests exhibited three factors (modes of financing, entrepreneurship development, monitoring and supervision) have a significant positive relationship with firm performance. Management of credit products related to the repayment, amount of loans disbursed and repayment period is ascertained as a major issue among the microcredit scholars and practitioners. Disbursements approach (Estapé-Dubreuil \& Torreguitart-Mirada, 2010; Guttman, 2007) as practiced in the Grameen Bank system and modeled by many other microcredit programs, flexible repayment schedule (Armendáriz \& Morduch, 2005) and payback period (Guttman, 2007; Derban et al., 2005; Sharma \& Zeller, 1997) appear to have a significant impact on the performance of the program and partaking MSEs. Consistent with the results by Fatimah Salwa et al. (2013), Eze and Ibekwe (2007), and Guttman (2007), total loans also affect the positive relationship between the method of financing and MSE's performance.

Social development programs are a counterpart of a credit product. In line with Ubeda-García, (2005), AragónSánchez et al. (2003), Fraser et al. (2002) and Zinger et al. (2001), the findings explain the existence of a positive relationship between entrepreneurship development programs and performance. Monitoring and supervision are very critical for the service delivery microcredit program. Customers need to be monitored with the use of loan capital as well as given guidance and advice in harnessing entrepreneurship values. Studies carried out by Bhatt et al. (1999) and Khandker et al. (1995) empirically show that support services have a significant positive association with the performance of MSEs'.

According to the findings, the influence of credit product management in terms of operational efficiency which including the approval of the loans, service charges or interest rate, loan terms and conditions on the relationship between microcredit programs and MSEs' performance is not significant. These findings suggest that the mechanism that be evaluated in operational efficiency does not affect the relationship between microcredit and MSEs' performance. This study also confirms the argument by Hart (1995) that only a unique resource will become strategic assets to the firm. Studies show that operational efficiency in the microcredit program is not a unique source compared to the element modes of financing, entrepreneurship development, monitoring and supervision. Based on the research findings, RBV theory emphasizes the role of internal resources which may be appropriate to be associated with large-scale firms, but it is not very significant to micro-sized enterprises in developed countries. From the perspective of policies and strategies, the study reminds policymakers and practitioners of microcredit programs that interest financing management aspects (modes of financing) and social development programs (entrepreneurship development and customer support services) are critical for the development of the organizations offering microcredit schemes and the performance of joining MSES. 
Credit assistance and support services need to have distinctive characteristics besides have been equipped with a unique service delivery system to ensure that the program has a clearer affirmative influence on MSEs' performance. This notion is important because business failure is not only due to MSEs' financial constraints, but also lack of skills, knowledge and entrepreneurship values.

\section{Limitation and Future Research}

The main focus of this study is to examine the impact of microcredit programs and program delivery system on the performance of MSEs. Despite its own strength, this study also has some limitations. The study analyzes the various elements associated with the practice of the delivery system in the preparation of credit products and social services. There are several mechanisms that microcredit programs may consider to include as elements in the system of service delivery. These elements include compulsory savings, savings mobilization customers and insurance schemes involved. In addition, the practice of using information technology in management can be analyzed and became the focus of research as suggested by Johansson and Olhager (2004). Comparative analysis between microcredit programs should also be done to explore the mechanism more effectively in influencing the performance of MSEs. This is basically due to the different possible economic and political effects on the service delivery system.

\section{References}

Alam, S. (2013). The impact of credit and non-credit aspects on self-employment profit: A comparison of microcredit programs and commercial lenders in rural Bangladesh. The Journal of Developing Areas, 47, 23-45.

Ang, M. H. (2004). Empowering the poor through micro credit. International Journal of Entrepreneurship \& Innovation Management, 4, 485-494.

Anku-Tsede, O. (2014). Microfinance intermediation: Regulation of financial NGOs in Ghana. International Journal of Law and Management, 56, 274-301.

Aragon-Sánchez, A., Barba-Aragün, I., \& Sanz-Valle, R.. (2003). Effect of training on business result. International Journal of Human Resource Management, 14, 956-980.

Arinaitwe, S. K. (2006). Factors constraining the growth and survival of small scale businesses: A developing countries analysis. The Journal of American Academy of Business, 8, 167-178.

Armendáriz, B., \& Morduch, J. (2010). The economics of microfinance. Cambridge: MIT Press.

Asian Development Bank. (2000). Finance for the poor: Microfinance development strategy. Manila: Asian Development Bank.

Barney, J. (1991). Firm resources and sustained competitive advantage. Journal of Management. 17, 99-120.

Bateman, T. S., \& Snell, S. A. (1999). Management building a competitive advantage. (4th ed.). Boston: Irwin/McGraw-Hill.

Berg, G. (2010). Evaluating the impacts of microsaving: The case of Sewa Bank in India. Journal of Economic Development, 35, 75-96.

Berko, L., \& Gueullette, A. (2003). Policy for support of small and medium-size enterprises in Hungary: The case of the central region. Post-Communist Economies, 15, 243-257.

Bhatt, N., Painter, G., \& Tang, S. Y. (1999). Can microcredit work in the United States? Harvard Business Review, 77, 26-27.

Bank Negara Malaysia, (2007), The Malaysian economy in 2006: SME annual report 2006. [Online] Available: http://www.bnm.gov. my/files/publication/ar/en/2006/cp01_001_whitebox.pdf

Brand, M. (2000). More bang for the buck: Improving efficiency. MicroBanking Bulletin, 4, 13-18.

Bruwer, J. D. W., \& Haydam, N. E. (1996). Human capital investment: Higher educational and on-the job training of the marketing practitioner. South African Journal of Business Management, 27, 1-8.

Che Zakiah, C. D. (2004). Creating a conducive environment for micro and rural finance-The Malaysian experience. In Proceedings of the High-level Policy Meeting on Microfinance and Rural Finance in Asia.

Chinomona, R. (2013). Business owner's expertise, employee skill training and business performance: A small business perspective. Journal of Applied Business Research, 29, 1883-1896.

Christen, R. P. (1997). Banking services for the poor: Managing for financial success: An expanded and revised guidebook for microfinance institutions. Somerville: ACCION International.

Colman, R. (2006). Microcredit management support. CMA Management, Disember/January, 53-54.

Conroy, J. D., (2002), Microfinance in Malaysia: Time to rebuild. [Online] Available: http://www.bwtp.org/publications/pub/AIM_paper.htm

Copestake, J., Bhalotra, S., \& Johnson, S. (2001). Assessing the impact of microcredit: A Zambian case study. The Journal of Development Studies, 37, 81-100.

Deininger, K., \& Liu, Y. (2009). Determinants of repayment performance in Indian micro-credit groups. Policy Research Working paper No. 4885, The World Bank.

Dokulilova, L.. Janda, K., \& Zetek, P. (2009). Sustainability of microfinance institutions in financial crisis. Munich Personal RePEc Archive Paper No. 17696, 1-24.

Draft, R. (1983). Organization theory and design. New York: West Publishing.

Derban, W. K., Binner, J. M., \& Mullineux, A. (2005). Loan repayment performance in community development finance institutions in the 
UK. Small Business Economics, 25,319-332.

Estapé-Dubreuil, G., \& Torreguitart-Mirada, C. (2010). Microfinance and gender considerations in developed countries: The case of Catalonia. Management Research Review, 33, 1140-1157.

Eze, C. C., \& Ibekwe, U. C. (2007). Determinants of loan repayment under the indigenous financial system in Southeast, Nigeria. The Social Sciences, 2, 319-332.

Farrington, T. (2000). Efficiency in micofinance institutions. MicroBanking Bulletin, 4,1823.

Fatimah Salwa, A. H., Mohamad Azahari, A., \& Joni Tamkin, B. (2013). Success factors of successful microcredit entrepreneurs: empirical evidence from Malaysia. International Journal of Business and Social Science, 4, 153-59.

Fraser, S., Storey, D., Frankish, J., \& Robert, R. (2002). The relationship between training and small business performance: An analysis of the Barclays Bank small firms training loan scheme. Environment and Planning: Government and Policy, 20, 211-233.

Gadenne, D. (1998). Critical success factors for small business: An inter-industry comparison. International Small Business Journal, 17 , 36-51

Goldstein, S. M., Johnston, R., Duffy J., \& Rao, J. (2002). The service concept: the missing link in service design research? Journal of Operations Management, 20, 121-134.

Getubig, I., Remenyi, J., \& Quinones, B. (1997). Creating the vision: Microfinancing the poor in Asia-Pacific: Issues constraints and capacity building. Kuala Lumpur: Asian and Pacific Development Centre.

Gibbons, D. S. (1994). The Grameen reader. (2nd ed.). Dhaka: Grameen Bank.

Gibbons, D. S., \& Meehan, J. W. (1999). The microcredit summit challenge: Working towards institutional financial self-sufficiency while maintaining a commitment to serving the poorest families. Journal of Microfinance/ESR Review, 1, 131-192.

Guttman, J. M. (2007). Repayment performance in microcredit programs: Theory and evidence. Networks Financial Institute, Indiana State Uiveristy, Working Paper No. 2007-WP-11, 1-18.

Hart, S. L. (1995). A natural resource-based view of the firm. Academy of Management Review, 20, 986-1014.

Hill, A. V., Collier, D. A., Froehle, C. M., Goodale, J. C., Metters, R. D., \& Verma, R. (2002). Research opportunities in services process design. Journal of Operations Management, 20, 189-202.

Hietalahti, J., \& Linden, M. (2006). Socio-economic impacts of microfinance and repayment performance: A case study of small enterprise foundation. South Africa. Progress in Development Studies, 6, 201-210.

Hulme, D., \& Mosley, P. (1996). Finance againts poverty. London: Routledge.

Hung, C. R. (1999). From south to north: A comparative study of microcredit programs in developing and developed countries. In 21st Annual Research Conference of the Association for Public Policy Analysis and Management, November 4-6.

Johansson, P., \& Olhager, J. (2004). Industrial service profiling: Matching service offerings and processes. International Journal of Production Economics, 89, 309-320.

Khandker, S. R., Khalily, M. B., \& Khan, Z. H. (1995). Grameen Bank: Performance and sustainability. World Bank Publications.

Khandker, S. R., Samad, H. A., \& Khan, Z. H. (1998). Income and employment effects of micro-credit programmes: Village-level evidence from Bangladesh. Journal of Development Studies, 35, 96-124.

Khandker, S. R. (1999). Microcredit to advance women. Grameen Dialogue, $37,3$.

Kotey, B., \& Meredith, G.G. (1997). Relationship among owner/manager values, business strategies and enterprise performance. Journal of Small Business Management, 35, 37-64.

Kwortnik R. J., \& Thompson, G. M. (2009). Unifying service marketing and service operations with service experience management. Journal of Services Research, 4, 389-406.

Light, I., \& Pham, M. (1998). Beyond creditworthy: Microcredit and informal credit in the United States. Journal of Developmental Entrepreneurship, 3, 35-51.

Makina, D., \& Malobola, L. M. (2004). Impact assessment of microfinance programmes, including lessons from Khula Enterprise Finance. Development Southern Africa, 21, 799-814.

McDonald, J. (2000). Credit unions: Efficient and profitable financial intermediaries. The MicroBanking Bulletin, 4.

McKernan, S. M. (2002). The impact of micro credit programs on self-employment profits: Do noncredit program aspects matter? The Review of Economics and Statistics, 84, 93-115.

Mohammed Ashraful, H., \& Harbin, J. L (2009). Micro Credit: A different approach to traditional banking: Empowering the poor. Academy of Banking Studies Journal, 8, 1-13.

Norma, M. S. (2011). Selecting high-income generating activities for micro-entrepreneurs: The case study of Amanah Ikhtiar Malaysia. International Journal of Humanities and Social Science, 1, 258-264.

Norma, M. S., \& Jarita, D. (2010). Determinants of economic performance of micro-credit client and prospect of Islamic microfianance in Malaysia. ISRA International Journal of Islamic Finance, 2, 113-130.

Nunnally, J. C. (1978). Psychometric theory. (2nd ed.). New York: McGraw-Hill.

Obamuyi, T. M. (2009). Credit delivery and sustainability of micro-credit schemes in Nigeria. Journal of Enterprising Communities, 3, 7183.

Painter, G., \& Tang, S. Y. (2001). The microcredit challenge: A survey of programs in California. Journal of Development Entrepreneurship, 6, 1-16.

Pellegrini, F. (2015). Microcredit in Italy: Searching for a model. 9th International Scientific Conference: Economic and Social Development, pp. 329-340.

Pereira, S., \& Mourao, P. (2012). Why does the microcredit borrowing rate differ across countries? A cross country study. International 
Journal of Social Economics, 39, 536-550.

Ponsignon, F., Smart, P. A., \& Maull, R. S. (2011). Service delivery system design: Characteristics and contingencies. International Journal of Operations Production Management, 31, 324-334.

Porter, M. E. (1981). The contributions of industrial organization to strategic management. Academy of Management Review, 6, 609620.

Raviez, R. M. (1998). Searching for sustainable microfinance: A review of five Indonesian initiative. World Bank Publications.

Reddy, M. (2007). Small business in small economies: Constraint and opportunities for growth. Social and Economic Studies, 56, 304321.

Richardson, M. (2009). Increasing microlending potential in the United States through a strategic approach to regulatory reform. Journal of Corporation Law, 34, 923-942.

Roslan, A., \& Karim M. (2009). Determinants of microcredit repayment in Malaysia: The case of Agrobank. Humanity and Social Sciences Journal, 4, 45-52.

Rosman, M., \& Mohd Rosli, M. (2013). Microcredit position in micro and small enterprise performance: The Malaysian case. Management Research Review, 36, 436-53.

Rubach, M. J., Bradley, D. B., \& Brown, J. E. (2010). The determinants of the success of microlending: A comparison of Iraq and the United States. International Journal of Entrepreneurship, 14, 59-70.

Rumelt, R. P. (1984). Towards a strategic theory of the firm. In B. Lamb (Ed.), Competitive strategic management. (pp. 556-570). New Jersey: Prentice Hall.

Sarap, A. (2014). Success and constraints of group lending programs: Evidence from the working of micro-credit institutions in Odisha. South Asian Journal of Management, 21(1), 65-83.

Seibel, H. D., \& Parhusip, U. (1998). Attaining outreach with sustainability: A case study of a private microfinance institution in Indonesia. IDS Bulletin, 4, 81-90.

Sekaran, U. (1992). Research methods for business: A skill-building approach. (2nd ed.). New York: John Wiley \& Sons.

Sharma, M., \& Zeller, M. (1997). Repayment performance in group based credit programs in Bangladesh: An empirical analysis. World Development, 25, 1731-1742.

Simpson, M. Tuck., \& Bellamy, S. (2004). Small business success factors: The role of education and training. Education and Training, 8 , 481-491.

Singh, S. R. (2012). Micro finance programmes in India-An overview. Anusandhanika, 4, 23-30.

Sukor, K. (2000). Impact of banking on rural poor in peninsular Malaysia: Final report of external impact evaluation study on AIM active borrowers, non-borrowing members, dropouts and non-participating poor. Penang: Centre for Policy Research, Universiti Sains Malaysia.

Tax, S. S., \& Stuart, I. (1997). Designing and implementing new services: the challenges of integrating service systems. Journal of Retailing, 73, 105-134.

Tehrani, M., \& White, C. S. (2003). Economic development and micro-enterprises in rural communities: Are there gender differences? Journal of Business Studies, 9, 26-41.

Ubeda-García, M. (2005). Training and business performance: The Spanish case. International Journal of Human Resources Management, 16, 1691-1710.

Webster, B., Walker, E., \& Brown, A. (2005). Australian small business participation in training activities. Education and Training, 47, 552-561.

Woller, G., \& Woodworth, W. (2001). Microcredit as a grass-roots policy for international development. Policy Studies Journal, 29, 267282.

Woodworth, W. P. (2000). Third world economic empowerment in the new millennium: Microenterprise, micro entrepreneurship and microfinance. Advanced Management Journal, 65, 19-26.

Zapalska, A. M., Brozik, D., \& Rudd, D. (2007). The success of micro-financing. Problems and Perspectives in Management, 5, 84-90.

Zeller, M., Schrieder, G., Von Broun, J., \& Heidus, F. (1997). Rural finance for food security for the poor: Implications for research and policy. Food Policy Review, 4, 83-110.

Zinger, J. T., LeBrasseur, R., \& Zanibbi, L. R. (2001). Factors influencing early stage performance in Canadian microenterprise. Journal of Developmental Entrepreneurship, 6, 129-150. 